\title{
The iPad Pilot Project: A Faculty Driven Effort to Use Mobile Technology in the Reinvention of the Liberal Arts
}

\author{
Mark K. McBeth', Kandi Turley-Ames², Yolonda Youngs ${ }^{3}$, Laura Ahola-Young ${ }^{4}$, \\ and Amy Brumfield 5
}

\begin{abstract}
Mobile technology is pervasive in society and in particular among young people. The use of such technology in the classroom can be controversial, and case studies and data on student perceptions of the technology are rare. This study presents the results of an iPad Pilot Project sponsored by a college at mid-sized university in the intermountain western United States. The study intersects the use of the iPad in the classroom with the reinvention of liberal arts education. Using case studies and student perceptions from survey data, the study concludes that the innovative use of the iPads in the classroom can enhance critical thinking, student collaboration, and classroom participation. The study also details some different pedagogical challenges of using the iPad in the classroom.
\end{abstract}

Keywords: iPads, mobile technology, pedagogy

\section{Introduction}

While collaboration (George, 1994), critical thinking (Grossman, 1994), and (today) brain based learning (Bowman, Frame \& Kennette, 2013) are regularly thought of as key elements of the college classroom, it is rare that these three essential elements of teaching are discussed within the context of mobile learning. In fact, to many faculty members, technology inhibits collaboration, critical thinking, and student learning. Yet with the exception of one study (Diemer, Fernandez, \& Streepey, 2012), there has been little empirical research on how iPads influence student perceptions of learning and engagement and how faculty members teaching with iPads deal with the pedagogical challenges arising with their use. The iPad Pilot Project (iPP) at Idaho State University seeks to answer some of the questions that the use of technology has raised in higher education.

The iPP began with the idea that all students need exposure to technology as a collaborative and problem-solving tool that complements (not replaces) human interaction. The iPP also began with the simultaneous ideas that the use of mobile technology had to be driven from the grassroots through faculty experimentation and discussion of the use of the technology in the classroom.

\footnotetext{
1 Associate Dean, College of Arts \& Letters, Idaho State University

2 Dean, College of Arts \& Letters, Idaho State University

${ }^{3}$ Assistant Professor, Department of History, Idaho State University

${ }^{4}$ Assistant Professor, Department of Art, Idaho State University

${ }^{5}$ Ph.D. candidate, Department of English and Philosophy, Idaho State University
} 


\section{Background}

There is a common misconception that technology and a liberal arts education are on two opposite ends of a continuum. The liberal arts classrooms are, by design, intensely interactive, and some instructors see technology as interfering with the faculty/student interaction. Faculty in the iPP, however, saw the potential of leveraging technology in the liberal arts to facilitate student engagement and further develop the foundational skills that are critical for a quality undergraduate education. Recently, the importance of a liberal arts education, as opposed to narrowly focused technological training has been a topic of significant discussion in academic circles, including the Chronicle of Higher Education (Beecroft, 2013; Berman, 2013; Berrett, 2013) and Association of American Colleges \& Universities (Humphreys \& Kelly, 2014), and in nonacademic circles, including the Wall Street Journal (Cappelli, 2013) and New York Times (Brooks, 2013; Klinkenborg, 2013). These studies conclude that there is an immediate need in U.S. society for college

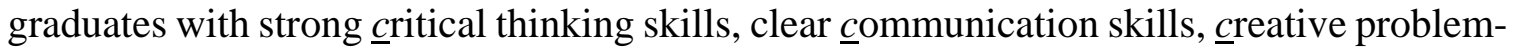
solving skills, $\underline{c}$ areer-related skills (which often includes technological skills), cultural competency, and the ability to $\underline{c}$ ollaborate. (These are often referred to in our College as the six "Cs."). In other words, employers are looking for graduates with an intellectual profile and transformative skills that will prepare them to operate successfully in a global society and meet workforce expectations into the future. As educators, we need to identify strategies to integrate foundational critical liberal arts abilities such as critical thinking, collaborative learning, and technological skills to better prepare students for a broad range of careers.

\section{The Project}

In the spring of 2013, the College of Arts \& Letters at Idaho State University launched the iPP as an experiment to encourage liberal arts faculty members in the humanities, fine arts, and social sciences to introduce mobile technology into their classrooms. Our project goals included seeing how instructors could use technology to deepen their students' understanding of their disciplines, how students could interact in more meaningful ways with the academic material and with each other, and how faculty could use technology to solve pedagogical challenges. This paper presents case studies and data from the project including how different instructors used this technology, the pedagogical foundation that guided them, the results that they observe, and student perceptions of the iPP.

Kandi Turley-Ames, Dean of the College of Arts \& Letters, Associate Dean Mark McBeth, and Director of Development Heidi Jarvis-Grimes decided to launch the iPP after consultation with faculty members over an emerging interest in mobile technology in the classroom nationwide. The college would purchase iPads, invite instructors to apply to use them, and then furnish each student with an iPad for classroom use.

Journal of Teaching and Learning with Technology, Vol. 4, No. 1, June 2015. jotlt.indiana.edu 


\section{Planning the iPP}

This project was designed as a collaborative effort between college administrators and faculty. Like any experiment, literature was reviewed both before and during the experiment and was used to guide the development, implementation, and evaluation of the iPP. One element of the iPP that was informed by literature was the creation of faculty learning communities (Cox, 2003). The idea of faculty learning communities lead the iPP to avoid any temptation to define exactly how the mobile technology would be used before it was purchased.

Second, the iPP considered many valid concerns found in teaching journals and more general literature about inviting (more) technology into the classroom. Nationwide, faculty views of technology and learning are mixed. Some critics see technology as a tool that is replacing faculty expertise in the classroom (Bromwich, 2014; Kolowich, 2013) and larger societal critics see technology as replacing and harming human interactions (Postman, 1993: Ritzer, 2011). Proponents like Cathy Davidson (2011), however, see technology opening a new frontier of student-instructor collaborations and she sees the technology as only improving (not harming) student and faculty interactions. Thus, the iPP hoped to explore and wrestle with the question of whether technology encourages or hinders student learning.

Third, the iPP also embraced the five principles proposed by Doering (2007). Using Doering's (2007, p. 2) words, there must be an "obvious pedagogical need;" otherwise, the use of such technology will appear gimmicky. Next, Doering argues that the use of mobile learning must be based on a pedagogical approach that is grounded in both the theory and practice of teaching. Additionally, the technology should be inexpensive for users. Finally, Doering argues that mobile learning technology should be easy to use and free from technical errors and that the use of mobile technology ultimately should be "empirically proven by monitoring and evaluation studies" (Doering, 2007, p. 2).

Finally, the iPP based some of their evaluation on work by Diemer and colleagues (2012) in evaluating the iPP. The authors of this study measured student comfort levels, student preferences for e-learning, and perceived engagement. The study found that nearly $85 \%$ of students were comfortable with the devices, $85 \%$ had at least a moderate preference for e-learning, and that there was a moderate correlation between engagement and levels of learning (Diemer, et al. 2012, 18-21).

\section{Methods}

The iPP was developed to allow the instructors to push the boundaries of their pedagogy by handing them a new tool that has the potential to enhance pedagogy. The goal was to test this concept as widely as possible. iPP administrators selected undergraduate and graduate courses as well as content and methods courses. In the first semester of the project (fall 2013), iPP administrators selected seven instructors representing a range of disciplines to participate in the program: art, history, composition, anthropology, public administration and policy analysis (political science). Another four faculty members joined in spring 2014. Project participants met regularly in person and through the online message

Journal of Teaching and Learning with Technology, Vol. 4, No. 1, June 2015. jotlt.indiana.edu 
board to collaborate and assist each other to experiment with ways to use mobile technology in the classroom.

Since the iPP was built from the ground up, determining how to evaluate the program proved challenging. The iPP leadership group eventually settled on four faculty members that would share their experiences with the iPP in the form of case studies. The case studies of four faculty members represent a sample of the faculty members who taught in the first year of the iPP. The case studies included in this study were from faculty in History, Art, English, and Political Science. The goal of the case studies was to highlight common pedagogical challenges raised in the project and discuss how faculty met these challenges.

In order to measure student perceptions, a survey was designed based on initial project goals and feedback from the midterm meeting. The survey was placed on SurveyMonkey, and a link was sent to faculty for distribution to students at the end of the fall 2013 semester. The survey was also administered in the spring of 2014. One hundred and eighteen students that had enrolled in an iPP class completed the survey during the 2013-2014 school year. The students reported their agreement or disagreement with statements related to the courses as well as statements about their own technological preparation, and the role of technology in society. The survey answered four research questions:

Research Question \#1: What were student perceptions of the iPP?

Research Question \#2: What were the different ways, according to students, that the iPads were used in the classroom?

Research Question \#3: Were there differences in perceptions of the iPP between technologically savvy students and less technologically sophisticated students?

Research Question \#4: Were there difference in perceptions of the iPP between Humanities/Fine Arts courses and Social Science courses?

While the case studies and survey helped us address the four research questions, the iPP additionally had faculty submit comments in writing at both the midterm and final meetings of the fall 2013 semester. Some of these comments are included in the results section in order to provide more context to the data. Students also could submit comments in the student survey and some of these comments are also included.

In the future, the iPP leadership group plans to continue to compile data that will contribute insights to long-term research questions regarding whether iPads in the classroom can increase enrollment, improve retention, build career-based skills, and improve learning among both undergraduates and graduate students.

\section{Case Studies: Pedagogical Challenges}

This section of the paper describes the pedagogical challenges that were faced by faculty members in the iPP and how four faculty members addressed these challenges. Four of our instructors and co-authors submitted case studies from the arts, humanities, and social sciences.

Journal of Teaching and Learning with Technology, Vol. 4, No. 1, June 2015. jotlt.indiana.edu 
Pedagogical Challenge: How do we prepare our students to enter a digitally enhanced workplace?

Students' future employers expect that college graduates will be critical thinkers with excellent communication skills (Berrett, 2013). In today's world, however, students are also expected to be digitally fluent (Pannapacker, 2013). While Idaho State University has traditional students arriving straight out of high school, we also have non-traditional students who come back to school after realizing that they are unprepared for the job market. Our students have a range of technological skills which are determined as much by socioeconomics as age. As Instructor Brumfield found in her English composition courses, younger students tend to be more tech savvy than older ones, but age is not the only factor. There were older students who could run a small computer lab from their backpacks and back pockets, while some of her young students turned in essays that they struggled to write on WordPad as evidenced by the excruciating lack of spell check.

Nearly all of our students use technology for their personal use, but poverty and rural location both limit how much some of our students have access to the basic programs of the work force like word processing. It is a vicious cycle. Those with the least exposure to technology at home often have the weakest writing skills. They are at a significant disadvantage in the collegiate system, and they are in desperate trouble in the professional world.

All of our graduates need to be comfortable using technology, know its capabilities and limitations, and, perhaps most importantly for this digital generation, know when to set it aside. College must prepare them to represent themselves articulately both in person and the digital world. Our classrooms can help our students to question technology, pushing them to see how it can build a professional network as fast as a social one or how to use an existing technology in a new way. With the use of mobile technology, we can help them apply their critical thinking skills to their digital worlds.

In a study conducted by the Association of American Colleges and Universities (Humprehys and Kelly, 2014) 4 out 5 employers agreed that students should have a broad knowledge in the liberal arts and sciences. Further, 93 percent of employers agreed that the ability to think critically, communicate clearly, and solve complex problems was more important than a student's chosen major. Finally, employers indicated that they wanted to hire individuals who have knowledge that is specific to their field but also broad enough to collaborate with many different disciplines or fields.

To that end, the iPP faculty participants developed new ways to introduce technology and critical information skills into their classrooms. For example, Instructor Brumfield uses mobile devices to show her composition students what digital writing tools are available to help them write, research, cite, and collaborate online. In particular, she found that many of her freshmen struggled to know how to take notes in lecture. So, Instructor Brumfield creates a collaborative Google doc for each class period and then takes breaks within the lectures for everyone to do some collaborative note taking. Students can practice formalizing their thoughts, see what their colleagues caught that they missed, and interact with each other about the content that they gathered. Students collaborate on

Journal of Teaching and Learning with Technology, Vol. 4, No. 1, June 2015. jotlt.indiana.edu 
content while they either gather or share their technological experience. Everyone has access to a deeply developed page of notes to study after they leave class. Equally importantly, Instructor Brumfield can see in real time what information was gathered and what obviously needs to be covered in more depth.

\section{Pedagogical Challenge: How do I engage students with multiple learning styles?}

In learning theory, students learn in different ways. Some students learn best in noisy environments; others need quiet. Some learn best in formal classroom settings structured around lecture lessons while others thrive in informal classrooms filled with vigorous debate. Students learning styles can be auditory, visual, and kinesthetic (for a longer review of learning styles see Denig, 2004). Effective instructors use a wide mix of learning experiences to engage each kind of student.

Professor Youngs used a variety of iPad activities in an upper division environmental history course. One of Professor Youngs's course goals was to explore mobile learning technology boundaries using a situated, or place-based, learning approach. Students used iPads both in and out of the classroom to complete an original archival and field-based research project that blended the method of repeat photography with cultural geography and environmental history approaches, and extended traditional research boundaries through collaborative and social media technology.

The repeat photography exercise with the iPads presented multiple approaches to active learning and problem solving. Students related their experiences for each campus or downtown session through short, written entries in a class blog as their digital field journals. After each field day, Professor Youngs held a debriefing session by displaying the class blog on the classroom projection screen and encouraging students to exchange ideas and techniques they posted in the blog and explored during the field sessions. The exercise connected in and out-of-class activities and reinforced class concepts through repetition and review of materials in different contexts. Students quickly used this in-class activity time to reflect on their blog comments, discuss technical issues with their iPads, peer review other students' comments, and help each other to solve the challenges of capturing accurate repeat photography while describing historic landscape changes.

The iPads served as useful tools to engage students with multiple learning styles including text, visual, and oral communication using a variety of apps, digital resources, visual multimedia presentations, and hands-on learning techniques. Students gained valuable technology skills for job preparation, improved their research abilities, explored collaborative learning strategies, and learned course content in a variety of contexts.

Pedagogical Challenge: How do we make the classroom more like the real world?

Leamnson (1999, p. 39) suggests that increasingly students find college courses as disconnected from real-world problems and view higher education as a "contrived and artificial system." With this cynical view, higher education becomes nothing more than a game played by students. Students take tests, write papers, but see little connection between what they are doing and the "real world" that they inhabit. Leamnson $(1999$, p. 39) writes, "[s]tudents are quite prepared to play a game by any rules we lay down, but they do not take readily to mixing up 'school facts' and their real beliefs."

Journal of Teaching and Learning with Technology, Vol. 4, No. 1, June 2015. jotlt.indiana.edu 
Ironically, the traditional classroom reinforces this dynamic in many ways. While our goal is to push students to think critically and to offer unique solutions to the world's problems, some instructors tend to do this by offering a set of concrete materials to master. Instructors select the reading and lecture materials as well as the ways that our students are evaluated on those materials. Indeed, students study us at least as much as they study our material, looking for clues about how they will be evaluated. It is a strategy that has served them well in their education and employment up to this point. Many of our students hold jobs where they are expected to perform assigned tasks, not to question how those tasks are done. They may assume that success inside and outside the classroom will be measured by how precisely they can regurgitate required materials to show that they reached the exact same conclusion as their instructor or employer, as it has been up to this point.

Professor Youngs engaged her students in a variety of learning styles using iPads. Professor Youngs's research expertise lies in digital technologies and many of Professor Youngs's classes are focused on teaching students how to use geospatial and digital technologies. In class, she modeled a peer-review method by showing the students historic and contemporary repeat photograph sets from their published or ongoing repeat photography research projects. Professor Youngs then encouraged the students to review her photo sets and discuss the accuracy, historical context, and challenges of using this method. Students used the iPads to explore online, digital photography collections hosted by museums and local historical associations that featured historical images of campus and downtown Pocatello. On field days, students used their photo evaluation skills practiced in the classroom to teach each other in their "backyards" on campus and at various locations in downtown. Students visited field site locations on campus and downtown where they created their own photo sets, compared them to their peers' imagery, and sought advice from their fellow students about their photos' accuracy and the historical landscape change.

Students used the iPads to connect course content with real-world applications and innovative technologies. The iPads allowed students to have hands-on experience in environments outside of the typical classroom setting. Through this process, they gained valuable technology skills in preparation for a variety of jobs in digital fields, improved their research abilities, explored collaborative learning strategies, and learned course content in a multiple of real-world contexts.

While there is foundational knowledge that simply must be learned, real world solutions to complex problems are rarely found by seeking out the answers of one expert. We usually stumble upon problems, reach out to widely varying sources, and integrate the results, often as a team (e.g., Surowiecki, 2005). Employers expect that college graduates are critical thinkers who can collaborate to solve the problem of their industries.

In the art studio, for example, the iPad creates a space for students to organize, save, and have their own "digital" space. Professor Ahola-Young creates an environment where students are using the iPad to organize their portfolio. This portfolio is an absolute necessity for students in a digital age. Having a digital archive allows the public, potential galleries and design companies direct access to an artist's work. Like David Burns (2010) expressed, "Historically, space and capital limitations restricted the public's accessibility to artwork, but the growth of mass digital reproduction and alternative forms of art exhibition space is having a profound effect on the valuation of digital media arts work."

With the iPad, students become active members, citizens even, of the digital

Journal of Teaching and Learning with Technology, Vol. 4, No. 1, June 2015. jotlt.indiana.edu 
(global) community. Students are able to travel the contemporary art world and find artists they relate to. Professor Ahola-Young further encourages students to engage with the larger art community through the iPad by researching images and contemporary artists while in the studio classroom.

Pedagogical Challenge: I am an expert in X, not technology. What/how could I possibly teach with it?

Some faculty members dread introducing more technology in their classroom because our disciplines do not focus on technology as part of our learning materials. Some of us may feel like we are ill equipped to teach with technology, and that instruction is best left to more specialized instructors. Many of our disciplines are not (at least not yet) focused on the integration of electronic materials into our course content. Particularly in the liberal arts, we may focus a great deal of our time on interpersonal communication. We design spirited debate and critical thinking exercises that engage students with each other and their instructors. There is an expectation that instructors will be experts in the materials that they present. Essentially, this means that our debates with students are largely rhetorical. These debates aim instead to check the students' understanding rather than expanding our own. Integrating technology can unsettle this expectation by encouraging and sometimes forcing us to ask open questions with unknown answers.

This goes against convention. Traditionally, classroom college teaching focused on lecturing as the major pedagogical tool of the college teacher (i.e., the "sage on the stage"). While lecturing continues to play an important role in the college classroom, the exclusive use of lecturing has fallen out of favor in academic circles as studies in learning theory (e.g., Ambrose et al., 2010; Leamnson, 2009) have led many faculty to use a more dynamic, student-centered, and mixed-methods approaches in the classroom. This new pedagogical model showcases the faculty member as not only a content expert but also a facilitator of learning. Importantly, in this model of teaching, the shift in focus in the classroom moves from the professor to the students and specifically the students' learning. This is sometimes referred to as "flipping the classroom" (Brame 2013; Davidson, 2011, Mangan, 2013; Potter, 2013). Rajasingham (2011, p. 5) argues in this regard that mobile learning can "provide the bridge for communications and interactions between learner, teacher, knowledge, and problem as a collaborative process, in synchronous (real-time) systems."

When Instructor Brumfield first learned that she would have access to mobile technology in her English 1101 course, her first thought was "Those could be so helpful" and her second thought was "This is bound to go badly for awhile." While Instructor Brumfield likes technology, she has not the slightest doubt that many of her students use technology far more efficiently and creatively than she does. Her primary worry was that she would waste valuable class time struggling with technology and that the course content would suffer, taking her credibility along with it.

Though doubts loomed, Instructor Brumfield took this risk because professional writing has expanded far past simple word processing. We know earlier that Instructor Brumfield used a collaborative Google docs. In fact, many documents are developed collaboratively and disseminated through a multitude of platforms. While she knows well how the arguments and mechanical skills need to be developed, she thought it entirely

Journal of Teaching and Learning with Technology, Vol. 4, No. 1, June 2015. jotlt.indiana.edu 
possible that her students will have a wider range of ideas about how to collaborate during the writing process and how to disseminate the finished products. Instructor Brumfield's goal was ask to questions that allowed for very open pathways to find answers, in the hopes of expanding her own knowledge along with her students.

Pedagogical Challenge: How do we get our students to think critically and push beyond their first predictable response to a question?

Particularly in the humanities and social sciences, there has been much discussion about retooling education to better connect graduates to workplace needs without sacrificing intellectual quality (Berrett, 2012; Jenkins, 2011; Pannapacker, 2013; Potter 2013). The liberal arts already excel at teaching our students how to see problems from a variety of angles, how to formulate the right questions, and how to seek answers in unconventional places. Employers seek out our graduates because they are curious and creative, write clearly, research well, learn quickly, and have excellent critical thinking skills (Pannapacker, 2013). We wanted to see where technology could help push students to ask rigorous research questions so that they could find innovative answers-first in a classroom and later in a career.

Professor Ahola-Young designs her art classes so that her art students not only think critically, but also see critically. Students often rely on cliché imagery when faced with the proverbial "blank canvas." Using the iPad to access additional information (e.g., images) opens up various possibilities for students to push past what previously had seen like obvious "solutions." Drawing requires considerable stillness and contemplation, art is a visual language and to communicate effectively means to design well. With the iPad in hand, students are able to evaluate image possibilities before ever touching pencil to paper. Students demonstrate less anxiety and frustration when able to play with the camera and drawing apps (e.g., Sketchbook express) then they typically do when using only paper. All art students, even professional artists, realize that an artworks meaning (for both the maker and the viewer) is open, can change over time, and is interpreted in many ways. As Lambert (2006) argues, "In art production, students seek solutions for how to convey meaning with visual imagery; and in critiquing art they seek answers on interpreting the work of others. Neither type of inquiry is clear or straightforward" (216). As artists, we have no control over this process but are constantly deeply engaged within it through dialogue, active looking, critiques, revisions, and questioning. Because works of art have multiple meanings, these investigations by students inevitably lead to critical thinking. Research shows that learning in the arts is largely inquiry based and that "A consensus of findings in research on education and critical thinking indicates that an inquiry based curriculum positively influences gains in critical thinking" (Lambert, 2006, p. 216). Art Educators purposely create assignments that are open ended and ambiguous. As Steve Jobs said, "Creativity is just connecting things" (Wolf, 1999). The iPad, and apps for drawing, allow students to merge, connect, and layer images while maintaining the integrity of originals.

Pedagogical Challenge: How do I see what my students have grasped and what needs more clarification?

Journal of Teaching and Learning with Technology, Vol. 4, No. 1, June 2015. jotlt.indiana.edu 
Students learn best through active learning and problem solving (Edens, 2000; Smith et al., 2005). Problem-based learning is student-centered, uses group work, changes the role of the professor to one of a facilitator, presents problems to be solved, and creates a drive for self-learning in the student (Smith et al., 2000). According to Smith et al. (2005, pp. 8-9) a problem-solving approach to teaching promotes "positive interdependence" among students, "face to face" interactions between students and the professor, student responsibility, teamwork, and "group processing." Typically, such active learning deemphasizes the lecture in favor of cases, student simulations, role-playing, and other pedagogical methods (Leamnson, 1999, pp. 83-117).

A major challenge to problem-based learning (and indeed teaching as a whole) is to determine what a student has learned from it and where they still struggle. As Angelo and Cross (1993) argue, "students need to receive appropriate and focused feedback early and often" so that they can "assess their own learning" (9). While classroom assessment techniques (CATs) have been used for many years, the traditional classroom makes it difficult to offer immediate and personalized feedback. Often, the only personalized feedback a student receives from some instructors is on the test or essay she/he has already completed, which is far too late to help her/him learn. Some faculty wish we could peer inside our students' minds to see what they understand and where they need clarification.

Technology can get us closer to fulfilling that wish. For example, Instructor Brumfield was deeply frustrated by her composition students' prolific and repetitive grammar errors. More specifically, she was deeply frustrated by her inability to stop them. Because she only got to interact with a student's individual writing a few times a semester, there was little opportunity to see their problems and few effective ways to fix them. With the iPads in hand, she searched for ways that technology could let her interact with each of her students' writing in real time so that she could see the problems in development, where her lessons were failing to connect, and how to build those lessons differently to get a better, deeper understanding. She used programs like LectureTools and Socrative to do real time writing practice. Every student could submit an answer anonymously, their answers were gathered and displayed instantly, and every text could be discussed as a group without anyone feeling singled out for their mistakes. Indeed, most of the time, students could see that everyone made mistakes and that mistakes weren't fatal. Mistakes were even helpful since it allowed them to critically analyze what went wrong and how to make it right.

Equally importantly, Instructor Brumfield could see that she was presenting far too much information in one step. By watching her students struggle and carefully studying the pattern of mistakes, she could see that it takes a sophisticated series of semantic diagnoses to correctly place even a simple comma, which isn't the slightest bit simple to a novice writer. By having access to this level of feedback, she renovated her entire series of lessons to include more elementary information, much smaller steps, and clearer diagnostic markers to help her students see the logic behind their choices.

Pedagogical Challenge: Can mobile technology promote better classroom discussion and classroom interaction?

Some scholars have voiced a concern that technology, specifically social media and other communication platforms, are producing a society where we, as Turkle (2010)

Journal of Teaching and Learning with Technology, Vol. 4, No. 1, June 2015. jotlt.indiana.edu 
explains in the title of her book, are "alone together." The concern is that interpersonal relationships are lost in technologically mediated interactions (Bromwich 2014). Some faculty participants in the iPP worried that the use of iPads in the classroom would harm the vital interpersonal communication and discussion that occurs in a face-to-face classroom. Not only is such communication and discussion valued by faculty, but interpersonal communication is a key attribute of what the humanities and social sciences contribute to a student's intellectual growth. Yet, it is possible to find ways to retain and even enhance interpersonal communication with technology (e.g., Baym, 2010).

Professor McBeth was leery about introducing iPads into his upper-division and graduate level public policy analysis course. He specifically designs his course to have very active exchanges between his students and him, and he was justifiably worried that the iPads would break that dynamic. He slowly introduced small experiments into each threehour class and carefully watched to see how the dynamics of the class shifted. For example, he started posting questions to the class blog and had students respond to the questions as the class progressed. Those blog posts intensified the discussion, brought in a much wider range of student comments, and allowed all the students, especially his quieter ones, room to expand on their thoughts so that they could be more confident in jumping into the fray of discussion.

Encouraged by that success, Professor McBeth instituted the use of pre- and posttests. He created simple surveys about the class's material, posted the link, and received the results in real time. The students could actually see their individual and collective knowledge development change based on a night's worth of discussion. Altogether, he found that using the iPads strengthened the instructor/student dynamic, improved the students' relationships with each other, and showed the value of attending class and participating in the discussion rather than simply trying to glean information from a textbook.

\section{Quantitative Analysis of Student Perceptions}

\section{Research Question \#1: Student Perceptions of the iPP}

In Table 1, the data demonstrates that students were favorable to the mobile technology as a learning tool. Students were asked to rate their agreement or disagreement with each statement on a seven point scale. The questions were then collapsed into three categories for reporting purposes. Seventy-two percent of students understood the purpose of the iPads; $67 \%$ believed that the tool would assist them in their future careers; and $63 \%$ agreed that the iPads played an important role in critical thinking and collaboration in the classroom. The iPads also received significant support as a tool for student learning (58\% agreed), enhancing participation (57\%), and increasing student engagement (56\%). Fiftytwo percent of students agreed that they wanted to take another class that uses mobile technology. One student noted in the comments section of the survey that "I saw a huge value in using the touch pads for multiple reasons and would strongly agree that this is a step in the right direction for teaching."

Journal of Teaching and Learning with Technology, Vol. 4, No. 1, June 2015. jotlt.indiana.edu 
McBeth, M., Turley-Ames, K., Youngs, Y., Ahola-Young, L., \& Brumfield, A.

Table 1 Student Perceptions of the iPad

\begin{tabular}{|l|l|l|l|}
\hline Statement & \multicolumn{1}{|c|}{ Agree } & $\underline{\text { Neutral }}$ & $\underline{\text { Disagree }}$ \\
\hline $\begin{array}{l}\text { Student } \\
\text { learning }\end{array}$ & $65(58 \%)$ & $27(24 \%)$ & $21(18 \%)$ \\
\hline $\begin{array}{l}\text { Critical } \\
\text { thinking }\end{array}$ & $73(63 \%)$ & $18(16 \%)$ & $24(21 \%)$ \\
\hline Collaboration & $72(63 \%)$ & $21(18 \%)$ & $21(19 \%)$ \\
\hline $\begin{array}{l}\text { Student } \\
\text { engagement }\end{array}$ & $64(56 \%)$ & $20(18 \%)$ & $30(26 \%)$ \\
\hline Participation & $66(57 \%)$ & $24(21 \%)$ & $26(22 \%)$ \\
\hline $\begin{array}{l}\text { Another } \\
\text { class }\end{array}$ & $60(52 \%)$ & $28(24 \%)$ & $28(24 \%)$ \\
\hline $\begin{array}{l}\text { Assist in } \\
\text { career }\end{array}$ & $78(67 \%)$ & $21(18 \%)$ & $17(15 \%)$ \\
\hline Understood purpose & $83(72 \%)$ & $15(13 \%)$ & $18(15 \%)$ \\
\hline Distracting & $41(36 \%)$ & $25(22 \%)$ & $48(42 \%)$ \\
\hline $\begin{array}{l}\text { Technology } \\
\text { savvy }\end{array}$ & $84(72 \%)$ & $14(12 \%)$ & $18(16 \%)$ \\
\hline $\begin{array}{l}\text { Tech } \\
\text { good }\end{array}$ & $63(55 \%)$ & $33(29 \%)$ & $19(16 \%)$ \\
\hline Training & $52(44 \%)$ & $17(15 \%)$ & $48(41 \%)$ \\
\hline
\end{tabular}

Still referring to Table $1,72 \%$ of students agreed that they were technologically savvy; $55 \%$ of students agreed that overall technology is good for society; and $44 \%$ of students agreed they need more training. Interestingly, thirty-six percent of students felt that the iPads were distracting in the classroom. This latter finding is related to the need for more training as some faculty in the project noted initial difficulties in helping students use the technology in the classroom. Additionally, some students did not understand why the iPads were being used in the classroom. One student noted in the survey comment section that "I think it was unnecessary, because students use mobile devices primarily for personal reasons, not for classroom use."

Table 2 Student Perceptions of iPad Use, Purpose and Pedagogy

\begin{tabular}{|c|c|c|}
\hline \multicolumn{1}{|c|}{ Use } & Count & $\%$ \\
\hline $\begin{array}{l}\text { Hands on application, } \\
\text { solving problems, blogging }\end{array}$ & $70 / 118$ & $59 \%$ \\
\hline
\end{tabular}

Journal of Teaching and Learning with Technology, Vol. 4, No. 1, June 2015. jotlt.indiana.edu 
McBeth, M., Turley-Ames, K., Youngs, Y., Ahola-Young, L., \& Brumfield, A.

\begin{tabular}{|l|c|c|}
\hline Peer review/collaboration & $52 / 118$ & $45 \%$ \\
\hline $\begin{array}{l}\text { Discovery (exploring } \\
\text { concepts) }\end{array}$ & $79 / 118$ & $67 \%$ \\
\hline $\begin{array}{l}\text { Solve } \\
\text { puzzles }\end{array}$ & $13 / 118$ & $11 \%$ \\
\hline $\begin{array}{l}\text { Developing } \\
\text { skills }\end{array}$ & $54 / 118$ & $46 \%$ \\
\hline Multiple learning styles & $60 / 118$ & $51 \%$ \\
\hline Assessment/testing & $36 / 118$ & $31 \%$ \\
\hline Multimedia & $70 / 118$ & $59 \%$ \\
\hline $\begin{array}{l}\text { Critical } \\
\text { discussion }\end{array}$ & $33 / 118$ & $28 \%$ \\
\hline Portfolio building & $32 / 118$ & $27 \%$ \\
\hline Data collection & $65 / 118$ & $55 \%$ \\
\hline
\end{tabular}

Note. Questions asked only in spring 2014: taking surveys/polls (21/49, 43\%); research content areas $(32 / 49,65 \%)$

Research Question \#2: Student Perceptions of Uses of the iPads

Table 2 provides a student report of how they believed faculty used the iPads in the classroom. The most popular perceived uses were discovery (i.e., exploring concepts), hands on applications, multimedia presentations, data collection, and activities that appeal to multiple learning styles. Based on feedback from participating faculty, a new category was added for spring 2014, researching a content area, and $65 \%$ of students agreed that faculty used the iPads for that purpose.

Table 3 Technologically Savvy v. Technologically Unsophisticated Students

\begin{tabular}{|c|c|c|c|c|c|c|}
\hline$\underline{\text { Statement }}$ & $\begin{array}{l}\text { Fall } 201 \\
\text { Mean }\end{array}$ & $\begin{array}{l}13 \\
\text { SD } \\
\end{array}$ & $\underline{\mathrm{n}}$ & $\begin{array}{l}\text { Spring } \\
\text { Mean } \\
\end{array}$ & $\begin{array}{l}2014 \\
\underline{\text { SD }} \\
\end{array}$ & $\underline{\mathrm{n}}$ \\
\hline $\begin{array}{l}\text { Tool for learning } \\
\text { Savvy students } \\
\text { Unsophisticated }\end{array}$ & $\begin{array}{l}4.88 \\
3.75\end{array}$ & $\begin{array}{l}1.90 \\
1.49\end{array}$ & $\begin{array}{l}49 \\
12\end{array}$ & $\begin{array}{l}4.50 \text { ** } \\
2.17\end{array}$ & $\begin{array}{l}1.00 \\
1.60\end{array}$ & $\begin{array}{r}34 \\
6\end{array}$ \\
\hline $\begin{array}{l}\text { More Training } \\
\text { Savvy students } \\
\text { Unsophisticated }\end{array}$ & $\begin{array}{l}3.08 * * \\
4.78 \\
\end{array}$ & $\begin{array}{l}1.91 \\
1.98 \\
\end{array}$ & $\begin{array}{l}49 \\
12 \\
\end{array}$ & $\begin{array}{l}2.32 \\
3.00 \\
\end{array}$ & $\begin{array}{l}2.21 \\
1.41 \\
\end{array}$ & $\begin{array}{r}34 \\
6 \\
\end{array}$ \\
\hline $\begin{array}{l}\text { Assist in Career } \\
\text { Savvy students } \\
\text { Unsophisticated }\end{array}$ & $\begin{array}{l}5.40 * * \\
4.17\end{array}$ & $\begin{array}{l}1.53 \\
1.80 \\
\end{array}$ & $\begin{array}{l}49 \\
12 \\
\end{array}$ & $\begin{array}{l}4.91 * * \\
2.17\end{array}$ & $\begin{array}{l}1.41 \\
2.32 \\
\end{array}$ & $\begin{array}{r}34 \\
6 \\
\end{array}$ \\
\hline $\begin{array}{c}\text { Understood Purpose } \\
\text { Savvy students } \\
\text { Unsophisticated }\end{array}$ & $\begin{array}{l}5.56 * * \\
4.00\end{array}$ & $\begin{array}{l}1.31 \\
2.00 \\
\end{array}$ & $\begin{array}{l}49 \\
12 \\
\end{array}$ & $\begin{array}{l}4.94 * \\
3.33\end{array}$ & $\begin{array}{l}1.70 \\
2.07 \\
\end{array}$ & $\begin{array}{r}34 \\
6 \\
\end{array}$ \\
\hline
\end{tabular}

Note. $*$ p. $<.05 ; * *$ p. $<.01$ (unpaired t-test)

Journal of Teaching and Learning with Technology, Vol. 4, No. 1, June 2015. jotlt.indiana.edu 
Note. Students that self-identified as neutral in terms of technological savvy were not included in this analysis. Counter to our expectations, there was no association between age and technological savviness. The scale for the statements was 0 (strongly disagree) to 6 (strongly agree). Only statements that had significant differences were included in the table.

\section{Research Question \#3: Differences between Students and Technological Preparation}

Table 3 summarizes differences between technologically savvy self-identified students and technologically unsophisticated self-identified students by semester. Between the fall and spring semesters, less technologically sophisticated students were consistently less inclined to see the iPads as an important learning tool, less inclined to understand the purpose of the iPP, and less inclined to believe that the iPP would help their careers. Less technologically sophisticated students also believed that they needed more training.

Research Question \#4: Were there difference in perceptions of the iPP between Humanities/Fine Arts courses and Social Science courses?

Table 4 provides information on differences between faculty from the Humanities/Fine Arts and Social Sciences. Importantly, there were no significant differences between student evaluations of the iPP between the Humanities/Fine Arts and Social Sciences.

Table 4 Humanities and Social Science Comparisons on Core Statements

\begin{tabular}{|c|c|c|c|c|c|c|}
\hline Statement & Fall 2 & & & Spring & 2014 & \\
\hline & Mean & $\underline{\mathrm{SD}}$ & $\underline{\mathrm{n}}$ & Mean & $\underline{\mathrm{SD}}$ & $\mathrm{n}$ \\
\hline Tool for learning & & & & & & \\
\hline Humanities/Fine Arts & 3.50 & 1.74 & 30 & 4.62 & 1.80 & 13 \\
\hline Social Sciences & 3.84 & 1.94 & 37 & 3.79 & 1.77 & 34 \\
\hline Critical thinking & & & & & & \\
\hline Humanities/Fine Arts & 3.97 & 1.67 & 30 & 3.92 & 2.10 & 13 \\
\hline Social Sciences & 4.05 & 1.72 & 37 & 3.49 & 1.92 & 34 \\
\hline Collaboration & & & & & & \\
\hline Humanities/Fine Arts & 4.00 & 1.69 & 30 & 4.08 & 1.44 & 13 \\
\hline Social Sciences & 3.89 & 1.87 & 38 & 3.77 & 1.75 & 34 \\
\hline Engagement & & & & & & \\
\hline Humanities/Fine Arts & 3.83 & 1.78 & 30 & 3.23 & 2.13 & 13 \\
\hline Social Sciences & 3.76 & 1.82 & 38 & 3.43 & 1.87 & 34 \\
\hline Enhances participation & & & & & & \\
\hline Humanities/Fine Arts & 4.07 & 1.51 & 30 & 3.46 & 1.71 & 13 \\
\hline Social Sciences & 4.08 & 1.57 & 36 & 3.23 & 1.82 & 34 \\
\hline Assist in career & & & & & & \\
\hline Humanities/Fine Arts & 3.97 & 1.61 & 30 & 4.31 & 1.75 & 13 \\
\hline Social Sciences & 4.39 & 1.62 & 38 & 4.17 & 1.84 & 34 \\
\hline
\end{tabular}

Journal of Teaching and Learning with Technology, Vol. 4, No. 1, June 2015. jotlt.indiana.edu 
Note. None of the differences between the Humanities/Fine Arts and Social Sciences were significant at the .05 level, in a two-tailed, t-test.

\section{Discussion and Conclusion}

Faculty participants were generally pleased with the evaluations of students. Yet, it should be noted that there were a consistent 15 to 26 percent of students that self-reported that they did not benefit from the iPP. This negative finding might be explained partially by the rural and non-traditional nature of the student body at the university. A significant percentage of students at the university are older (average age of the student body is 28) and from rural areas where technology is still distant from the student's daily lives. In this group, even technologically sophisticated students can fail to see the importance of technology in their career futures. Also note that $55 \%$ of students (see Table 1) agreed that technology was overall good for society (with $29 \%$ neutral and $16 \%$ disagreeing). The fact that only $55 \%$ of students thought that technology is overall good for society is not necessarily a negative finding and instead the finding reflects the often critical stance that some faculty took toward technology in the classroom. Most faculty members reported in the learning community meetings that there were honest discussions in their classrooms about how technology impacts social interactions inside and outside of the classroom and these discussions were not always positive. A faculty member submitted a comment during the fall 2013 midterm learning community meeting that "students had some concerns about the use of technology and social media in the classroom including ethical concerns about labor practices and concerns about social media use in general."

The next step for the iPP will be to use controlled experiments with pre and posttests comparing student experiences in an iPP course with student experiences in a noniPP course. This initial survey data was invaluable in moving faculty toward that goal as it has identified (for one of the first times) how students view mobile learning.

The iPP provided several significant findings in regard to mobile technology use in the classroom. First, our data is consistent with and adds to the findings of Diemer, et al. (2012). For example, their data like our data, found that most students were comfortable using the iPads, that students had a preference for e-learning, and students felt that they both learned and were engaged using the iPads.

Second, we found that the basic principle of the iPP, that mobile technology use should be driven from the grassroots by faculty experiences was well supported. Our instructors discovered discipline-specific ways to utilize technology within their own classroom. By leaving the experiment open, the instructors had an unbounded creative space to do what we demand of our students: critically think our way through the existing problems to find novel solutions. Theory and research informed this project, but much of the success required simple trial and error with faculty and students in classroom experiences. Our preceding list of questions represents the many successes of the iPP. We could present an equally long list of lesson plans that went awry, wireless networks that vanished, Bluetooth connections that were dropped, and a myriad of other problems. This is an experiment, and like all experiments, we learned from both our failures and our successes.

Journal of Teaching and Learning with Technology, Vol. 4, No. 1, June 2015. jotlt.indiana.edu 
Third, while some faculty are concerned about technology replacing faculty expertise in the classroom (Kolwich, 2013), we found that our case studies reaffirm the essential value of faculty expertise. We agree with Doering (2007) that the use of mobile technology must fit a specific pedagogical need and that its use must be evaluated and tested. It cannot be stressed enough that technology - whether it is an iPad or pad of paper and pencil-does not teach. It is simply a tool. Our instructors' depth of knowledge, teaching experience, and creativity were central to the success of this project. Some of our instructors faced recurring pedagogical frustrations and were driven to find new ways to overcome the student learning impediments of their fields. The iPP provided a new tool to help instructors overcome those impediments.

Fourth, we found that it is possible to intersect technology with the current reinvention of the liberal arts. Based upon the data presented in this study and the ongoing discussion about the importance of liberal arts education from the perspective of employers (e.g., Berrett, 2012), we conclude that mobile technologies, such as the iPad, can facilitate the development of skills that are in high demand in our society and that prepare students not just for jobs but careers that can better withstand fluctuations in the economy.

Finally, one of the goals of the project was to determine the role of technology in the liberal arts and the better connection of the liberal arts to employer needs. We did not take this challenge lightly. There is an immediate need for graduates with strong critical thinking skills, cultural competency, clear communication skills, creative problem-solving skills, career-related skills (including technology skills), and the ability to collaborate. The iPP demonstrated that there does not necessarily have to be a dichotomy between the liberal arts and technology. Instead, technology can be used in a way that facilitates excellence in teaching and learning while also retaining the core strengths of a liberal arts education (and prepares students for careers rather than jobs).

\section{Acknowledgements}

The authors wish to acknowledge Dr. Ron Hatzenbuehler for his critical reading of an earlier draft of this paper. We also wish to acknowledge all of the faculty members in the College of Arts \& Letters who have taught in the iPP for the past two years.

\section{Appendix}

\section{Appendix 1: Survey Questions}

The purpose of this survey is to evaluate the use of mobile technology in the classroom using iPads. Your professor and the College of Arts and Letters will use the information from this survey to continue to improve mobile technology use in the classroom. The data from this survey will be used in a report written by the College of Arts and Letters assessing the use of iPads in the classroom. Your response is anonymous and the data will be aggregated into a report. Your participation is voluntary.

Journal of Teaching and Learning with Technology, Vol. 4, No. 1, June 2015. jotlt.indiana.edu 
Please rate your agreement or disagreement with the following statements (use the following scale: $0=$ strongly disagree to $6=$ strongly agree).

Please rate your agreement or disagreement with the following statements (use the following scale: $0=$ strongly disagree to $6=$ strongly agree). I think that mobile technology is an important tool for helping students learn. 0

a. I think that mobile technology is an important tool for helping students learn.

b. Mobile technology provided additional opportunities for critical thinking (analyzing, synthesizing, evaluation of information) in this course.

c. I consider myself technologically savvy.

d. I like to learn from other students and not just the professor and mobile technology provides an opportunity for student-to-student collaboration and group work.

e. Mobile technology in this class increased student engagement.

f. The use of mobile technology in face to face classes unnecessarily distracts from the learning environment.

g. Mobile technology enhances participation in a traditional classroom setting.

h. Mobile technology (like technology in general) is, overall, good for society.

i. $\quad$ I need more training on how to use mobile technology.

j. $\quad$ I am interested in taking courses that use mobile technology.

k. I see where using mobile technology in the classroom could assist me down in the road in my career or future career.

1. I understood the purpose for using mobile technology in this class.

Please indicate (by putting a check mark next to a category) whether how mobile technology was used in the class (choose as many as you think might apply):

Using mobile technology for hands on application (solving a problem, blogging, etc.) Using mobile technology for peer review/collaboration

Discovery (using mobile technology to explore different concepts in class)

Using mobile technology to solve puzzles

Developing skills using mobile technology

Using mobile technology to emphasize multiple learning styles

Using mobile technology for assessment/mobile testing

Using mobile technology for multimedia

Using mobile technology for a critical discussion of technology

Using mobile technology for portfolio building

Using mobile technology for data collection

Using mobile technology to take surveys or polls in class

Using mobile technology to research content areas

Demographic questions are excluded from this appendix.

Journal of Teaching and Learning with Technology, Vol. 4, No. 1, June 2015. jotlt.indiana.edu 
McBeth, M., Turley-Ames, K., Youngs, Y., Ahola-Young, L., \& Brumfield, A.

\section{References}

Ambrose, S.A., M.W. Bridges, M. DiPietro, M.C Lovett, and M.K. Norman. (2010). How Learning Works: 7 Research-Based Principles for Smart Teaching. San Francisco: Jossey Bass.

Baym, N.K. (2010). Personal Connections in the Digital Age. Malden, MA: Polity Press.

Beecroft, A. (2013). The humanities: what went right? The Chronicle of Higher Education. Retrieved April 14, 2014 from http://chronicle.com/blogs/conversation/2013/07/03/thehumanities-what-went-right/.

Berman, R. A. (2013). Humanist: heal thyself. The Chronicle of Higher Education. Retrieved April 4, 2014 from

http://chronicle.com/blogs/conversation/2013/06/10/humanist-heal-thyself.

Berrett, D. (2013). Harvard mounts campaign to bolster undergraduate humanities. The Chronicle of Higher Education. Retrieved April 4, 2014 from

http://chronicle.com/article/Harvard-Mounts-Campaign-to/139687.

Berrett, D. (October 8, 2012). Habits of mind: lessons for the long term. The Chronicle of Higher Education, Retrieved December 9, 2014 from http://chronicle.com/article/Habitsof-Mind-Lessons-for/134868/.

Brame, C.J. (2013). Flipping the Classroom. Center for Teaching, Vanderbilt University. Retrieved November 26, 2013 from http://cft.vanderbilt.edu/teaching-guides/teachingactivities/flipping-the-classroom/.

Bromwich, D. (August 14, 2014). The hi-tech mess of higher education." New York Review of Books, Vol. LXI (13), 50-51.

Bowman, M., Frame, D. L., \& Kennette, L. N. (2013). Enhancing teaching and learning: How cognitive research can help. Journal on Excellence in College Teaching, 24(3), 7-28 Brooks, D. (2013). The humanist vocation. The New York Times Sunday Review. Retrieved April 4, 2014 from http://www.nytimes.com/2013/06/21/opinion/brooks-the-humanistvocation.html?ref=davidbrooks.

Bunt, B.S. (2012). Media Art: Mediality and Art Generally. Leonardo: Art Science and Technology 45.1, MIT Press pp 94-95, Retrieved June 15, 2014 from http://www.mitpressjournals.org/doi/abs/10.1162/LEON_a_00348\#.U45h5q1dXXc.

Burns, D.R. (2010). The valuation of emerging media arts in the age of digital reproduction, Electronic Visualization and the Arts. London, UK, 259-264. Retrieved June 15, 2014 from http://ewic.bcs.org/content/ConWebDoc/36098.

Journal of Teaching and Learning with Technology, Vol. 4, No. 1, June 2015. jotlt.indiana.edu 
McBeth, M., Turley-Ames, K., Youngs, Y., Ahola-Young, L., \& Brumfield, A.

Cappelli, P. (2013). Why focusing too narrowly in college could backfire. Wall Street Journal, November 15. Retrieved April 4, 2014 from

http://online.wsj.com/news/articles/SB10001142412788732412940579016662718868576

Cox, M.D. (2003). Fostering the scholarship of teaching and learning through faculty learning communities. Journal on Excellence in College Teaching 14 (2/3): 161-198.

Davidson, C.N. (August 2011). Collaborative learning for the digital age. The Chronicle of Higher Education. Retrieved November 26, 2014 from http://chronicle.com/article/Insidethe-Flipped-Classroom/141891/.

Davidson, C. (January/February 2012). Dividing attention deliberately" In Skills Every 21st Century Manager Needs. Harvard Business Review, 129-143.

Denig, S.J. (2004). Multiple intelligences and learning styles: two complementary dimensions. Teachers College Record, 106 (1), 96-111.

Diemer, T.T., E. Fernandez, J.W. Streepey. (2012). "Student perceptions of classroom engagement and learning using iPads." Journal of Teaching and Learning with Technology $1(2), 13-25$.

Doering, N.M. (2007). The Mainstreaming of Mobile Learning at a German University. Proceedings of the Fifth Annual IEEE International Conference on Pervasive Computing and Communications Workshops (PerComW07). Retrieved December 7, 2013 from http://ieeexplore.ieee.org/xpl/articleDetails.jsp?arnumber=4144817.

Edens, K.M. (2000). Preparing problem solvers for the 21st Century through problem based learning. College Teaching 48(2), 55-60

George, P.G. (1994). The effectiveness of cooperative learning strategies in multicultural university classrooms. Journal on Excellence in College Teaching, 5(1), 21-30.

Grossman, R.W. (1994). Encouraging critical thinking using the case study method and cooperative learning techniques. Journal on Excellence in College Teaching, 5(1), 7-20.

Humphreys, D. and P. Kelly. (January 22, 2014). How Liberal Arts and Sciences Majors Fare in Employment: A Report on Earnings and Long-Term Career Paths. Association of American Colleges and Universities. Retrieved April 4, 2014 from https://www.aacu.org/nchems-report.

Jenkins, R. (July 6, 2011). The liberal arts are work-force development. The Chronicle of Higher Education. Retrieved December 9, 2013 from http://chronicle.com/article/TheLiberal-Arts-I-Are-I-/128149/.

Journal of Teaching and Learning with Technology, Vol. 4, No. 1, June 2015. jotlt.indiana.edu 
McBeth, M., Turley-Ames, K., Youngs, Y., Ahola-Young, L., \& Brumfield, A.

Kinash, S. J. Brand, and T. Mathew. (2012). Challenging mobile learning discourse though research: Student perceptions of Blackboard mobile learn and iPads. Australasian Journal of Educational Technology 28(4):639-655.

Klinkenborg, V. (2013). The decline and fall of the English major. The New York Times Sunday Review. Retrieved April 4, 2014 from http://www.nytimes.com/2013/06/23/opinion/sunday/the-decline-and-fall-of-the-englishmajor.html?ref=verlynklinkenborg\&_r=0.

Kolowich, S. (November 25, 2013). A truce on the tech front at San Jose State. The Chronicle of Higher Education. Retrieved November 25, 2014.

http://chronicle.com/article/A-Truce-Over-Technology/143229/?cid=at\&utm_source=at\& m_medium=en.

Lambert, N. (2006). Critical thinking dispositions as an outcome of art education. Studies in Art Education, Vol. 47, No. 3 (Spring, 2006), pp. 215-228._National Art Education Association, Retrieved June 15, 2014 from

http://www.jstor.org.libpublic3.library.isu.edu/stable/25475782.

Leamnson, R. (1999). Thinking About Teaching and Learning. Sterling, VA: Stylus.

Liao, Christine L. (March 2008). Avatars, Second Life ${ }^{\circledR}$, and New Media Art: The Challenge for Contemporary Art Education, Art Education, Vol. 61, No. 2, pp. 87-91.

Lundstrom, K. and W. Baker. (2009). To give is better to receive: The benefits of peer review to the reviewer's own writing. Journal of Second Language Writing 18(1), 30-43.

Mangan, K. (2013). Inside the flipped classroom. The Chronicle of Higher Education September 30. Retrieved November 26, 2014 from http://chronicle.com/article/Inside-theFlipped-Classroom/141891/.

Murray, O.T. and N.R Olcese. (2011). Teaching and learning with iPads, ready or not? TechTrends 55(6):42-48.

Pannapacker, W. (November 18, 2013). No more digitally challenged liberal-arts majors. The Chronicle of Higher Education, Retrieved December 9, 2013 from http://chronicle.com/article/No-More_Digitally-Challenged/143079/.

Postman, N. (1993). Technopoly: The Surrender of Culture to Technology. New York: Knopf.

Potter, C. (May 26, 2013). Could flipping the curriculum lead to more jobs and better educated students? The Chronicle of Higher Education, May 26. Retrieved December 9, 2013 from

Journal of Teaching and Learning with Technology, Vol. 4, No. 1, June 2015. jotlt.indiana.edu 
McBeth, M., Turley-Ames, K., Youngs, Y., Ahola-Young, L., \& Brumfield, A.

http://chronicle.com/blognetwork/tenuredradical/2013/05/could-curricular-change-leadto-more-jobs-and-better-educated-students/.

Purcell, K., J. Buchanan, and L. Friedrich. (July 16, 2013). The impact of digital tools on student writing and how writing is taught in schools. Pew Reports. July 16. Retrieved November 26, 2013 from http://www.pewinternet.org/Reports/2013/Teachers-technologyand-writing.aspx.

Rajasingham, L. (2011). Will mobile learning bring a paradigm shift in higher education? Education Research International, ArticleID 528495, 10 pages, doi:10.1155/2011/528495.

Ritzer, G. (2011). The McDonaldization of Society, $6^{\text {th }}$ edition. Los Angeles, CA: Sage.

Smith, K.A., S.D. Sheppard, D.W. Johnson, and R.T. Johnson. (January, 2005) Pedagogies of engagement: Classroom-based practices. Journal of Engineering Education: 1-15.

Surowiecki, J. (2005). The Wisdom of Crowds. Anchor Books. pp. xv. ISBN 0-385-721706.

Traxler, J. (2007). Defining, discussing and evaluating mobile learning: The moving finger writes and having writ... The International Review of Research in Open and Distance Learning 8(2): article 8.2.2. Retrieved December 7, 2013 from http://www.irrodl.org/index.php/irrodl/article/view/346/875.

Turkle, S. (2010). Alone Together: Why We Expect More From Technology and Less from Each Other. New York: Basic Books.

Wieder, B. (March 13, 2011). iPads could hinder teaching, professors say. Chronicle of Higher Education. Retrieved November 26, 2013 from http://chronicle.com/article/iPadsfor-College-Classrooms-/126681/.

Wolf, G. (February 1996). Steve Jobs: The next insanely great thing. Wired.com. Wired Digital, Inc., 01. Retrieved December 7, 2013 from

http://archive.wired.com/wired/archive/people/steve_jobs/.

Journal of Teaching and Learning with Technology, Vol. 4, No. 1, June 2015. jotlt.indiana.edu 